\title{
Efektifitas Kepemimpinan Lurah Dalam Meningkatkan Kesejahteraan Sosial Di Kelurahan Walawili Distrik Aimas Kabupaten Sorong
}

\author{
Irianti Umbingo ${ }^{1}$, Ana Lestari ${ }^{2}$, Laila Qadriyani Malikin Rumakat ${ }^{3}$ \\ ${ }^{1}$ Fakultas Ilmu Sosial Dan Ilmu Politik, Universitas Muhammadiyah Jakarta \\ ${ }^{2,3}$ Fakultas Ilmu Sosial Dan Ilmu Politik, Universitas Muhammadiyah Sorong \\ Email : alannalestari034@gmail.com
}

\begin{abstract}
ABSTRAK
Penelitian ini bertujuan untuk menganalisis Efektifitas Kepemimpinan Lurah dalam Meningkatkan Kesejahteraan Sosial di Kelurahan Walawili Distrik Aimas Kabupaten Sorong. Metode yang digunakan adalah Metode Deskriptif analisis, kemudian dalam penelitian ini dilakukan penarikan sampel dengan menggunakan teknik penarikan sampel purposif Sampling. Populasi dalam penelitian ini adalah Lurah dan seluruh Staf Kelurahan Walawili D istrik Aimas Kabupaten Sorong serta beberapa masyarakat warga kelurahan Walawili. Teknik pengumpulan data melalui studi dokumentasi dan studi lapangan melalui observasi dan Wawancara. Data di analisis secara kualitatif dan disajikan dalam bentuk diskriptif. Hasil penelitian yang dilakukan dapat disimpulkan bahwa Efektifitas Kepemimpinan Lurah dalam Meningkatkan Kesejahteraan Sosial di Kelurahan Walawili Distrik Aimas Kabupaten Sorong cukup bagus atau efektif. Namun dari beberapa temuan dari hasil penelitian menunjukan bahwa masih rendahnya perilaku kepemimpinan Lurah di dalam membantu memajukan karir bawahan, masih kurangnya peran masyarakat dan masih kurang jelasnya perincian program didalam penyusunan kegiatan pembangunan untuk kesejahteraan desa.
\end{abstract}

Kata Kunci : Efektifitas, Kepemimpinan, Kesejahteraan Sosial

\begin{abstract}
in Improving Social Welfare in the Walawili Village of Aimas District, Sorong Regency. The method used is a Descriptive analysis method, then in this study, a sample was collected using purposive sampling technique. The population in this study was the Village Head and all the Staff of the Walawili District of the District of Aimas, Sorong Regency and several residents of the Walawili village. Techniques for collecting data through documentation studies and field studies through observation and interviews. Data is analyzed qualitatively and presented in a descriptive form. The results of the research conducted can be concluded that the Effectiveness of the Village Head in Improving Social Welfare in the Walawili Village of Aimas District, Sorong Regency is quite good or effective. However, from several findings from the results of the study, it was shown that the low level of Lurah leadership behavior in helping to advance subordinate careers was still a lack of community roles and program details were still unclear in the preparation of development activities for village welfare.
\end{abstract}

Keywords : Effectiveness, Leadership, Social Welfare

188 Efektifitas Kepemimpinan Lurah Dalam Meningkatkan Kesejahteraan Sosial... 


\section{PENDAHULUAN}

Kelurahan dalam Undang-Undang Nomor 8 Tahun 2005 tentang Perubahan Atas Undang-Undang Nomor 32 Tahun 2004 tentang Pemerintahan Daerah merupakan kesatuan masyarakat hukum yang memiliki batas-batas wilayah yang berwenang untuk mengatur dan mengurus masyarakat setempat, berdasarkan asal-usul dan adat istiadat setempat yang diakui dan dihormati dalam sistem pemerintahan Negara Kesatuan Republik Indonesia.Jadi, Kelurahan merupakan wilayah gabungan dari beberapa Rukun Warga (RW). Kelurahan adalah pembagian wilayah administratif di Indonesia di bawah Distrik. Dalam konteks otonomi daerah di Indonesia, Kelurahan merupakan wilayah kerja Lurah sebagai Perangkat Daerah Kabupaten atau kota.

\begin{tabular}{ccc}
\multicolumn{2}{c}{ Dalam organisasi di tingkat } \\
Kelurahan Malawili Distrik Aimas
\end{tabular}
Kabupaten Sorong sebagai lapang penelitian, terdapat berbagai sumber daya, di antaranya adalah Sumber Daya Manusia (SDM).Namun, SDM tersebut tidak lagi dianggap sebagai faktor produksi semata, tetapi lebih dianggap sebagai asset organisasi yang penting. Keefektifan dan keunggulan organisasi sangat tergantung pada kualitas
SDM yang dimiliki.Secara teoritis, kualitas SDM dalam suatu organisasi yang tinggi diharapkan mampu meningkatkan pelayanan pada masyarakat. Hal ini akan dapat tercipta dalam suatu lingkungan kerja yang kondusif, yang antara lain dipengaruhi oleh tipe kepemimpinan yang tepat.

$$
\text { Kepemimpinan seseorang }
$$

dibutuhkan, karena adanya suatu keterbatasan dan kelebihan-kelebihan tertentu pada diri manusia tersebut. Disinilah timbulnya kebutuhan akan pemimpin dan kepemimpinan.Pemimpin dapat mempengaruhi moral, kepuasan kerja, keamanan, kualitas kehidupan kerja dan terutama tingkat prestasi suatu organisasi. Kemampuan dan keterampilan dalam pengarahan adalah faktor penting efektifitas suatu organisasi. Bila organisasi dapat mengidentifikasikan kualitas-kualitas yang berhubungan dengan kepemimpinan seseorang, maka kemampuan untuk menyeleksi pemimpin-pemimpin yang efektif akan meningkat.

Pada sebuah organsasi pemerintahan, kesuksesan atau kegagalan dalam pelaksanaan pelayanan masyarakat, dipengaruhi oleh kepemimpinan. Melalui kepemimpinan dan didukung oleh pemerintahan yang memadai, maka 
penyelenggaraan tata pemerintahan yang baik (Good Governance) akan terwujud, sebaliknya kelemahan kepemimpinan merupakan salah satu sebab keruntuhan kinerja organisasi tersebut (Istianto, 2009:2). Kepemimpinan (leadership), dapat dikatakan sebagaicara dari seorang pemimpin (leader) dalam mengarahkan, mendorong dan mengatur seluruh unsur-unsur dalam kelompok atau organisasinya, untuk mencapai suatu tujuan organisasi yang diinginkan sehingga menghasilkan pelayanan pada masyarakat dengan maksimal. Dengan meningkatkan mutu pelayanan, berarti tercapainya hasil kerja seseorang atau Aparatur Kelurahan dalam mewujudkan tujuan organisasi.Tugas pokok pemerintahan di tingkat kelurahan adalah menjalankan sebagian kewenangan Distrik serta melaksanakan tugas-tugas lainnya berdasar kepada peraturan yang berlaku.Dalam kapasitasnya sebagai sebuah organisasi pemerintah dibawah Distrik, tujuan penyelenggaraan pemerintahan kelurahan adalah terlaksananya berbagai fungsi kelurahan sesuai dengan kewenangannya yang diberikan oleh Distrik secara efektif dan efisien, termasuk di dalamnya adalah fungsi pelayanan administrasi aparat kepada masyarakat.
Efektifitas merupakan unsur pokok aktivitas organisasi dalam mencapai tujuan atau sasaran yang telah ditentukan sebelumnya.Bila dilihat dari aspek segi keberhasilan pencapaian tujuan, maka efektifitas adalah memfokuskan pada tingkat pencapaian terhadap tujuan organisasi. Selanjutnya ditinjau dari aspek ketepatan waktu, maka efektifitas adalah tercapainya berbagai sasaran yang telah ditentukan tepat pada waktunya dengan menggunakan sumber-sumber tertentu yang telah dialokasikan untuk melakukan berbagai kegiatan.Atas kepemimpinan Lurah Malawili tersebut, apakah berimbas pada peningkatan kesejahteraan masyarakat, atau sebaliknya.

Untuk mencapai kesejahteraan masyarakat di Kelurahan Malawili tersebut, hasil pengamatan awal menunjukkan bahwa kapasitas Lurah setempat berperan penting dalam upaya memotivasi dan menggerakkan segala potensi yang ada di masyarakat, atau memberikan bantuan material misalnya dari "Bantuan Desa" dll. Dengan demikian, terkait upaya peningkatan kesejahteraan masyarakat di Kelurahan Malawili tersebut di antaranya ditentukan oleh tingkat efektifitas kepemimpinan Lurah setempat. Dalam tataran dassain (kondisi riil di lapangan) menunjukkan, bahwa kesejahteraan 
masyarakat di Kelurahan Malawili masih rendah. Selanjutnya, pada tataran empiris bahwa kepemimpinan Lurah Malawili belum secara optimal mampu meningkatkan kesejahteraan masyarakat yang dipimpinnya.Begitu pula, masyarakat Malawili belum sepenuhnya bergairah dalam membangun daerahnya guna meningkatkan kesejahteraannya. Kepemimpinan Lurah Malawili belum sepenuhnya mampu menggerakkan staf di Kelurahan setempat, untuk bekerja optimal dan profesional dalam menjalankan tugas-tugasnya guna mencapai kesejahteraan masyarakat. Kepemimpinan Lurah sangat dibutuhkan untuk mengontrol berbagai kegiatan para pegawainya, apakah tugas fungsinya telah berjalan sesuai tujuan yang diinginan bersama atau tidak.

Lurah Malawili belum sepenuhnya mengoptimalkan segala potensi (resource) yang dimiliki para pegawainya, dalam bersinergi dengan segala potensi yang ada di masyarakat dalam memajukan daerahnya. dan pegawainya harus saling kerja sama dalam usaha pencapaian tersebut. masing-masing dari mereka haruslah menyadari tugas dan tanggungjawabnya. Pelayanan publik oleh Lurah beserta stafnya kepada masyarakat setempat belum dirasakan lebih baik dari sebelumnya.

\section{METODE PENELITIAN}

Metode yang digunakan dalam penelitian ini adalah metode deskriptif. Metode tersebut digunakan karena berusaha menemukan fakta tentang efektifitas kepemimpinan Lurah dalam meningkatkan kesejahteraan masyarakat di Kelurahan Malawili Distrik Aimas Kabupaten Sorong, dengan interpretasi yang tepat dan melukiskan secara akurat sifat dan tindakan dari fenomena kelompok maupun individu pada tataran empirik. Pendekatan/desain yang digunakan dalam penelitian ini adalah pendekatan kualitatif, karena mengamati dan menangkap realitas dan mengkaji perilaku individu dan kelompok serta pengalaman informan. Dalam penelitian ini, teknik pengumpulan data dilakukan dengan cara sebagai berikut : 1) Wawancara yaitu pengumpulan informasi dengan tatap muka langsung antara peneliti dengan informan sebagai responden. Pelaksanaan wawancara dilakukan secara mendalam (In Depth Interview) dengan Informan (Key Informant) menggunakan alat pedoman wawancara untuk mendapatkan data dan menggali informasi dari informan. 2) Observasi/pengamatan adalah penelitian yang pengambilan datanya bertumpu pada pengamatan langsung terhadap efektifitas 
kepemimpinan Lurah dalam meningkatkan kesejahteraan masyarakat di Kelurahan Malawili Distrik Aimas Kabupaten Sorong. 3) Dokumentasi yaitu berupa laporanlaporan, buku-buku/literatur yang terkait dengan judul penelitian. Sebagai instrumen pendukung, peneliti mempergunakan tape recorder, peta, kamera, buku catatan, alat tulis dan buku agenda yang berfungsi sebagai alat bantu dalam proses pengumpulan bahan dan data. Selanjutnya analisis data dalam penelitian ini berdasarkan perspektif emik dan etik, guna menghasilkan gambaran yang mendalam (thik description) dan menemukan makna (verstehen).

\section{HASIL DAN PEMBAHASAN}

Efektifitas Kepemimpinan Lurah Dalam Meningkatkan Kesejahteraan Sosial Di Kelurahan Malawili

Dalam UUD 1945 dijabarkan bahwa salah satu tujuan pembangunan nasional adalah memajukan kesejahteraan umum.Dalam arti sempit, indikator kesejahteraan melekat erat pada hal-hal berbau ekonomi bagaimana rakyat punya daya beli terhadap bahan bahan pokok. Dalam mewujudkan Kesejahteraan pemerintah tentu mempunyai program yang bertujuan membangun sistem dan dalam mendukung perekonomian masyarakatnya.
Dalam pengertian kesejahteraan kita tahu kesejahteraan bukanlah masalah ekonomi saja ada masalah kesehatan, masalah keamanan dan kedamaian.Dalam mewujudkan ini pemerintah terutama yang sekarang ini banyak mengeluarkan "kertu member" bagi orang yang kurang mampu agar bisa berobat.Walaupun masih kurang maksimal tentu saja kebijakan yang baik ini harus diapresiasi.

Dalam Undang-Undang Nomor 32 Tahun 2004 Tentang Pemerintahan Daerah sebagaimana perubahannya dalam Undang-Undang Nomor 12 Tahun 2008, serta Peraturan Pemerintah Nomor 73 tahun 2005 tentang Kelurahan, pasal 4, dijelaskan bahwa Lurah sebagaimana dimaksud dalam mempunyai tugas menyelenggarakan urusan pemerintahan, pembangunan dan kemasyarakatan. Selain tugas sebagaimana dimaksud, Lurah melaksanakan urusan pemerintahan yang dilimpahkan olehBupati/Walikota.Pembangunan yang dilaksanakan di pedesaan atau tingkat Kelurahan merupakan realisasi pembangunan nasional.Untuk menunjang pembangunan di pedesaan atau tingkat Kelurahan peran serta pemerintah serta partisipasi seluruh lapisan masyarakat sangat dibutuhkan. Dalam merealisasikan tujuan 192 Efektifitas Kepemimpinan Lurah Dalam Meningkatkan Kesejahteraan Sosial... 
pembangunan, maka segenap potensi alam harus digali, dikembangkan, dan dimanfaatkan sebaik-baiknya, demikian pula sumber daya manusia harus lebih ditingkatkan sehingga dapat mengembangkan potensi alam secara maksimal agar tujuan pembangunan dapat tercapai. Dalam hubungannya dengan meningkatkan kesejahteraan social, di Kelurahan Malawili Distrik Aimas Kabupaten Sorong sebagian besar diaprisiasikan dalam bentuk pembangunan pembangunan fisik sarana pedesaan dan pembangunan sumberdaya manusia dalam bentuk upaya untuk meningkatkan kesadaran masyarakat melalui program pemberdayaan masyarakat. Hal ini menjadi program utama yang dicanangkan oleh Lurah Walawili, karena kesejahteraan akan dapat tercapai dengan lebih baik bila kedua factor tersebut dapat berjalan bersama-sama.

\section{Kepemimpinan Lurah Dalam Meningkatkan Kesejahteraan Sosial Di Bidang Pembangunan}

\section{Kepemimpinan Lurah dalam Perencanaan}

Pemerintah kelurahan merupakan pemegang kendali dalam pembangunan di wilayah kelurahan. Oleh karena itu lurah beserta jajarannya merupakan penanggung jawab atas jalannya roda pemerintahan dan roda pembangunan sehingga maju mundurnya pembangunan di kelurahan tergantung dari kinerja pemerintah kelurahan dalam mempengaruhi masyarakatnya untuk turut serta di dalam pembangunan. Sebagaimana penyelenggaraan pemerintahan di desa yang merupakan wilayah setingkat dengan kelurahan, yang diatur dalam pasal 14 ayat (1) PP Nomor 72 Tahun 2005 ditegaskan bahwa Lurah mempunyai tugas menyelenggarakan urusan pemerintahan, pembangunan, dan kemasyarakatan. Berdasarkan hasil wawancara dengan pejabat pemerintahan bahwa untuk pembangunan di kelurahan Walawiwli cukup bagus, hal ini diungkapkan oleh Kepala Distrik Aimas seperti berikut : "Kalau masalah pembangunan di Kelurahan Walawili itu sudah sangat pesat mengingat di sini adalah perkotaan.Kondisinya sangat kompleks dan profesi warga cukup beragam, kendati demikian peran Lurah tetap sangat penting.Pemerintah kelurahan sangat berperan, kami berharap tetap melakukan pengawalan yang bijak demi terselenggaranya pembangunan yang intensif. Juga terus tingkatkan pelayanan yang baik kepada warga dan buka ruang yang sebebas-bebasnya kepada aspirasi 
masyarakat demi perkembangan, hal ini dipengaruhi oleh peran lurah sebagai pemimpin dalam melakukan perencanaan pembangunan, baik itu yang nantinya dilaksanakan secara swadaya, maupun dilakukan oleh pemerintah kota melalui dana APBD”. (Wawancara, 19 Nopember 2015).

Keadaan tersebut sesuai dengan hasil pengamatan yang dilakukan oleh peneliti, bahwa kondisi seperti jalan -jalan yang ada di lingkungan wilayah Kelurahan Walawili memang cukup bagus, sebagian besar sudah beraspaldan ada beberapa jalan yang sudah dalam kondisi pengerasan menggunakan hamparan batu kerikil bercampur pasir (sirtu). Kemudian ditambahkan oleh Kepala Kelurahan Walawili yang mengatakan bahwa : "Kelurahan Walawili adalah daerah yang memberi tantangan tersendiri buat kami dalam penyelenggaraan pemerintahan yang berbasis pembangunan. Di sektor pembangunan kami sebagai komponen pemerintah yang berada pada level paling bawah, hanya bisa mengusulkan berbagai pembangunan fisik, sementara pelaksanaannya tidak bisa kami pastikan karena semua ditangani oleh tingkat kota. Kami hanya bisa mengawal, dalam artian hanya sebatas menunjukkan lokasi yang dituju”. (Wawancara, 18 Nopember 2015).

Kedudukan Lurah sebagai kepala pemerintahan dan pembangunan serta pemimpin formal masyarakat sangatlah penting di dalam kelancaran pembangunan sehingga mengharuskan pemerintah kelurahan mempunyai aparatur dan pemimpin yang ahli di bidangnya, sehingga program dan tugas pemerintah dapat dilaksanakan dengan sebaik- baiknya. Hal di atas senada dengan hasil wawancara dengan seorang warga masyarakat Kelurahan Malawili seperti yang diungkapkan oleh Bpk Julius Mambraku, yang mengatakan :"Saya sangat senang bisa bekerja sama dengan seorang Lurah yang benar-benar dapat memberikan panutan dan pelayanan yang baik. Beliau juga sama sekali tidak membeda- bedakan semua warga yang membutuhkan pelayanan. Sehingga masyarakat bisa lebih berantusias dan berpartisipasi segala program pembangunan”. Untuk masalah pengambilan keputusan sendiri, Lurah selalu memperhatikan aspirasi dari semua kepala lingkungan dan ketua lembaga kemasyarakatan, ini bisa dianggap keterwakilan dari warga masyarakat. Hal ini senada dengan yang dikatakan oleh KASI Pemerintahan Kelurahan Malawili, bahwa : 
"Dalam setiap pengambilan keputusan, Lurah tidak pernah mengambil keputusan secara sepihak, ia selalu merundingkan dengan aparat lainnya, kepala lingkungan, dan ketua lembaga kemasyarakatan.Beliau pun tidak segan-segan untuk meminta saran dan pendapat dari kami". Hal ini menunjukkan bahwa Kelurahan Malawili dalam proses pelaksanaan pembangunan non fisik dengan cara selalu melibatkan unsur masyarakat dalam setiap ada kegiatan dan pengambilan keputusan. Hal ini membuktikan bahwa masyarakat di Kelurahan Malawili rasa kekeluargaan dan jiwa kebersamaannya masih erat terjalin walaupun Kelurahan Walawili merupakan salah satu daerah yang ikut dalam perkembangan penduduknya sangat komplek, terdiri dari berbagai suku dengan matapencaharian yang beragam.

\section{Kepemimpinan Lurah Dalam Mengkoordinasikan}

Aktivitas untuk memberi penjelasan dan arahan merupakan salah satu unsur yang sangat penting dalam pembangunan baik itu untuk perangkat kelurahan maupun untuk masyarakatnya. Tujuannya adalah agar perangkat kelurahan atau masyarakatnya itu tahu dan mengerti apa yang harus dikerjakan serta timbul kemauan untuk mengerjakan sesuatu sesuai kehendak lurah. Mengkoordinasikan/ Bimbingan, pembinaan, atau pengarahan dapat diartikan sebagai rangkaian kegiatan atau proses memelihara, menjaga, dan memajukan organisasi melalui setiap pelaksanaan tugas personal, baik secara struktural maupun fungsional, agar pelaksanaan tugas-tugas umum pemerintahan dan pembangunan tidak terlepas dari usaha mewujudkan tujuan negara atau cita-cita bangsa Indonesia. Perkataan pembinaan ini mempunyai cakupan kegiatan yang cukup banyak, akan tetapi yang jelas pembinaan mengandung arti pembangunan yaitu merubah sesuatu sehingga menjadi baru yang mempunyai nilai yang lebih tinggi dan juga mengandung makna sebagai pembaruan, yaitu usaha untuk membuat sesuatu menjadi lebih sesuai dengan kebutuhan, menjadi lebih baik dan lebih bermanfaat. Pihak pemerintah kelurahan menyadarir dan mengerti akantentang pentingnya pembinaan masyarakat. Seperti yang termaktub dalam Peraturan Pemerintah Nomor 73 Tahun 2005 tentang Pedoman Umum Penyelenggaraan Pemerintahan Desa. Hal senada juga diungkapkan oleh Ibu Agelina Tanamal, seorang aparat kelurahan yang mengatakan bahwa : "Ini merupakan salah satu langkah 
koordinasi dalam pelaksanaan pembangunan tapi koordinasi ini meliputi semua kepala lingkungan yang ada di kelurahan ini”.(Wawancara, 18 Nopember 2015)

\section{Kepemimpinan Lurah dalam melaksanakan Pengawasan}

Pengawas dalam pembangunan merupakan hal yang wajib dilakukan oleh seorang lurah, mengingat dari pengawasan yang dilakukan lurah dapat menentukan kualitas dari hasil pekerjaan pembangunan tersebut. Hal ini tentunya adalah kemampuan mempraktekkan ilmu teori kepemimpinan kepada orang yang dipimpinnya yang kenyataannya tidak selalu sama dengan yang diajarkan dalam ilmu teori kepemimpinan. Wawancara dengan Bapak Kamtari, seorang petani yang sekaligus tokoh masyarakat, yang mengatakan bahwa: "Hasil dari pembangunan yang ada dapat terjaga dengan baik, hal ini disebabkan karena pengawasan yang terus menerus dilakukan oleh lurah, sedangkan kalau masalah keamanan disini, cukup aman mungkin karena kepala lingkungan selaku orang tua yang cukup disegani itu semua dikoordinir dengan baik oleh pegawai di kelurahan. Biasanya kalau ada acara disini, yang punya acara meminta izin dulu di kantor kelurahan dan baru di berikan izin kalau mau bekerjasama dengan anak muda yang ada disini. Jadi kamanan terjamin karena anak muda di sini juga yang menjaga". (Wawancara, 18 Nopember 2015)

Hal yang serupa juga diungkapkan oleh Bapak Mardiono, seorang warga yang juga sebagai kepala RT di Lingkungan, mengatakan : "Saya rasa Lurah yang sekarang ini beruntung karena sudah tidak pernah lagi ada perkelahian antar pemuda. Dan biasanya kalo ada orang yang bermasalah perbatasan tanahnya bisa diselesaikan di kantor Lurah saja, diselesaikan secara kekeluargaan saja, hal ini turut menunjang proses pelaksanaan pembangunan itu sendiri”.(Wawancara, 18 Nopember 2015). Hal senada juga diungkapkan oleh sekretaris kelurahan, mengatakan : "Keamanan di sini bisa dikatakan cukup terjamin, karena Lurah mampu mengambil langkah kinerja yang di kordinasikan bersama dengan kepala lingkungan yang termasuk orang yang dituakan oleh warga. Dan kalau ada kejadian masalah keamanan yang perlu penanganan pihak yang berwajib kita semua cepat tanggap karena bagusnya kordinasi apalagi sekarang sudah aktif BABINSA, pengawasan lurah dalam pelaksanaan pembangunan sudah cukup baik, hal ini ditandai dengan hadirnya lurah untuk memeriksa pelaksanaan 
pembangunan itu sendiri, baik sementara dikerjakan, maupun setelah selesai dikerjakan". (Wawancara, 19 Nopember 2015). Salah Satu Masyarakat, Bpk D. A mengatakan : "Dalam masalah aspirasi warga, Lurah di sini selalu memberikan kesempatan sebaik mungkin kepada kami untuk mengeluarkan aspirasi. Beliau tidak pernah segan untuk mendengarkan keluhan warga apalagi kalau ada rapat di aula kantor kelurahan, begitu pun kalau hanya mendengarkan dalam pergaulan Lurah selalu terbuka kepada kami. Meskipun tidak ada pertemuan langsung keluhan warga juga bisa dibawakan oleh kepala lingkungan atau tokoh masyarakat lainnya". (Wawancara, 19 Nopember 2015). Kemudian ditambahkan lagi oleh bpk M selaku kepala lingkungan, mengatakan bahwa : "Semua aparat di Kantor Kelurahan Walawili ini bekerjasama dengan baik dalam penerimaan aspirasi masyarakat, kalaupun ada yang ingin mengeluarkan pendapatnya kita semua bisa tampung dan nanti disampaikan langsung kepada Lurah.Hal itu pun sudah diamanatkan oleh beliau kepada kami”. (Wawancara, 19 Nopember 2015).

Dalam hal pembahasan aspirasi dari masyarakat pihak Kelurahan biasa melakukan rapat kelurahan, termasuk menghadirkan tokoh-tokoh masyarakat dalam acara Musrenbang (Musyawarah Perencanaan Pembangunan).Biasanya lurah hanya mengundang perwakilan dari masyarakat saja seperti tokoh-tokoh masyarakat dan yang dianggap berkompeten dalam hal itu. Bpk H. A mengatakan : "Dalam hal pembangunan kami biasanya diundang untuk menghadiri acara MUSRENBANG.Yang diundang biasanya hanya tokoh masyarakat dan orang tertentu saja agar rapat dapat berjalan lancar dan agar tujuannya dapat tercapai". (Wawancara, 19 Nopember 2015). Hal senada diungkapkan oleh ibu C. W yakni : "Kalau menurut saya, Lurah orangnya sangat terbuka, saya bisa katakan karena saya biasa hadir di setiap rapat-rapat membahas masalah dana yang diterima pemerintah. Bahkan jumlah dana pun tidak pernah disembunyikannya. Pada saat pertemuan aspirasi masyarakat pun selalu ia butuhkan, agar bantuan dana yang masuk ini bisa benar-benar merata". (Wawancara, 19 Nopember 2015).

Sesuai dengan pengamatan penulis, di kantor Kelurahan Walawili terlihat adanya kesan yang sangat antusias dari aparat kelurahan jika ada warga yang yang berkunjung langsung dilayani dengan baik. Kalau keperluan warga berupa 
pengurusan administrasi aparat langsung menjelaskan secara terperinci apalagi kalau yang bersangkutan adalah warga yang masih awam dengan persuratan.Kalau tarif yang dipungut atas pengurusan administrasi itu aparat kelurahan tidak pernah memasang tarif apalagi meminta, hanya saja warga yang langsung memberi yang disertai dengan ucapan terima kasih.

Hal senada juga diungkapkan oleh salah satu aparat perangkat kelurahan yang biasa menguruskan keperluan administrasi warga mengatakan : "untuk urusan administrasi di kantor sini, kami tidak memasang tarif tertentu kami hanya mengatakan seikhlasnya saja dan yang bersangkutan merasa tidak dirugikan. Kami semua menjelaskan urusan administrasi itu termasuk kalau harus diselesaikan di ibukota kabupaten kan di sini hanya diberi surat pengantar kalau memang yang bersangkutan bisa urus sendiri maka kami tidak lagi direpotkan jadi dia bawa sendiri. Jadi kita berusaha memberi pelayanan sebaik 2015).

\section{KESIMPULAN}

Kesimpulan yang dapat penulis tarik adalah sebagai berikut : 1) Efektivitas kepemimpinan lurah dalam meningkatkan kesejahteraan masyarakat melalui bidang pembangunan di Kelurahan Malawili dapat dlihat dari adanya upaya pengawalan yang intensif dari pihak aparat pemerintahan kelurahan beserta jajarannya yang bekerjasama dengan Kepala Lingkungan, tokoh masyarakat. Sebagai pemerintah tingkat bawah pemerintah kelurahan hanya bisa mengusulkan serta mendampingi semua pembangunan secara fisik yang ditetapkan oleh hasil MUSRENBANG di tingkat Distrik. Karena pemerintah kelurahan hanya bisa menjalankan perintah, kordinasi dari pemerintah tingkat Distrik yang merupakan wilayah administrasinya. Untuk lebih lanjutnya peranan pemerintah kelurahan dalam pembangunan dapat dilihat dari beberapa indicator sebagaimana sudah diuraikan secara mendalam pada bab pembahasan. 2) Faktor yang mempengaruhi efektivitas kepemimpinanlurah dalam meningkatkan kesejahteraan masyarakat melalui pembangunan di Kelurahan Walawili terdiri dari: adanya antusias yang tinggi serta partisipasi masyarakat, dan kerjasama antar sesama aparat yang dikontrol oleh Lurah yang merupakan pemimpin dalam kelurahan.

\section{DAFTAR PUSTAKA}

Antoni, F, 2006.Pengaruh Gaya Kepemimpinan Orientasi Tugas dan Orientasi Hubungan terhadap 
Motivasi Kerja dan Dampaknya pada

Prestasi Kerja Pegawai Pengadilan Tinggi Tata Usaha Negara Surabaya, [Tesis], Program Pascasarjana, Universitas 17 Agustus: Surabaya.

Aritonang, K. T, 2005.Kompensasi Kerja, DisiplinKerja Guru dan Kinerja Guru SMP Kristen BPK Penabur, Jakarta, Jurnal Pendidikan Penabur - No,04 / Th,IV/ Juli 2005.

Blanchard, Miller, 2005. The Secret-Rahasia Kepemimpinan, Jakarta, Elex Media Komputindo.

Bolden, R., Gosling, J., Marturano, A. and Dennison, P, 2003. A Review of Leadership Theory and Competency Frameworks. Centre for Leadership Studies, University of Exeter. UK.

Barata, Atep Adya, 2003. Dasar-Dasar Pelayanan Prima, Persiapan Membangun Budaya Pelayanan Prima Untuk Meningkatkan Kepuasan dan Loyalitas Pelanggan, Jakarta: Elex Media Komputindo.

Creswell, John W, 2002. Researh Design. Quanlitative\&Quantitative

Approaches. New York: Sage Publication, Inc.

Chourmain, Imam, 2003. Manajemen Pelayanan Publik.Jakarta: Badan Pendidikan dan Pelatihan Departemen Dalam Negeri Republik Indonesia.

Dwiyanto, Agus, 2005. Mewujudkan Good Governance Melalui Pelayanan
Publik. Yogyakarta: Penerbit Gadjah Mada University Press. Cetakan pertama.

Darwin, Muhadjir, M, 2005. Memanusiakan Rakyat : Penanggulangan Kemiskinan Sebagai Arus Utama Pembangunan. Yogyakarta :Benang Merah

Djohan, Djohermansyah, 2003. Kebijakan Otonomi Daerah 1999.Jakarta: Yasrif Watampone.

Higgs, M, 2003. How can we make sense of leadership in the 21st century?, Leadership and Organi Organizational Development Journal, hal. 273-284.

Hendel, Tova, Miri Fish \&VeredGalon, 2003.Leadership style and choice of strategy in conflict Managemen tamong Israeli nurse managers in general hospitals, International Education Journal, Vol. 4 No. 3, 2003, http://www.iej.cjb.net.

Hamlin, R, 2007. Developing effective leadership behaviours: the value of evidence based Management, Business Leadership Review IV:IV October 2007, UK.

Kerlinger, Fred N, 2000. Azas-azas Penelitian Behavioral. Alih Bahasa Landung R Simatupang. Yogyakarta: Gajah Mada University Press. Edisi Ketiga.

Kartono, Kartini, 2001. Pemimpin dan Kepemimpinan. Cetakan 
Kesembilan, Jakarta: Raja Grafindo

Persada.

Moleong, Lexy J, 2006. Metodologi Penelitian

Kualitatif. Bandung: Penerbit PT.

Remaja Rosda karya- Cetakan

Kesebelas.

Muchji, Moch dan B. Suko Priyono, 2011.

Pengaruh Gaya Kepemimpinan

Transaksional Terhadap Kinerja

Karyawan Yang Di moderasi Gaya

Kepemimpinan Transformasional,

Telaah Managemen, Vol.1 Edisi 2, hal. 236- 256.

Nawawi, $2003 \quad$ Kepemimpinan

Menggerakkan Organisasi, UGM

Pr: Yogyakarta.

Nawawi, Hadari, dan Hadari, Martini.2003.

Kepemimpinan Yang Efektif,

Yogyakarta, Gadjah Mada

University Press, Cetakan Pertama.

Ndraha, Taliziduhu, 2003. Metodologi

Pemerintahan Indonesia, Cetakan

III, Jakarta: Bina Aksara, hlm 57.

Sugiyono. 2007. Metode Penelitian

Administrasi. Bandung:Alfabeta.

Edisi Ke-12.

Widjaja, HAW. 2005. Penyelenggaraan

Otonomi Di Indonesia.Jakarta: PT.

Raja Grafindo Persada.

Yukl, Gary A, 2000.Managerial Leadership:

A Review of Theory and Research,

Journal of Manage ment, hal. 251-

289. 